\title{
The Impact of Using the Tourist Attraction of Tukad Bindu and Tukad Badung in Denpasar
}

\author{
Nyoman Agus Trimandala ${ }^{1, *}$ \\ ${ }^{1}$ Post Graduate Program in Management, Universitas Pendidikan Ganesha, Singaraja, Indonesia \\ ${ }^{*}$ Corresponding author. Email: nyomanagustrimandala@gmail.com
}

\begin{abstract}
Revitalization of Tukad Bindu and Tukad Badung is one of the goverment's effort which are collaboration with people to add the tourist attraction and improve environment quality of Denpasar City. The aims of this study to describe about potential characteristics of Tukad Badung and Tukad Bindu which are related with the impact of teir economy, social and their environment. The data was conducted through observation, interviews, study documentation and qualitative descriptive analysis. The implementation showed that the potential possessed by Tukad Bindu and Badung was very diverse. Tukad Bindu has many activities that can be carried out by visitors. Besides that, the economic, socio-cultural, and environmental impacts were very clearly felt by the surrounding community such as new jobs and increased public awareness of the environment. In addition, the economic, socio-cultural, and environmental impacts are very clearly felt by the surrounding population. Getting new jobs, and the attitude of the public who are enthusiastic about the visit of tourists also impact of Tukad Badung.
\end{abstract}

Keywords: impact, revitalization, river, tourist attraction.

\section{INTRODUCTION}

A "Tourist attraction" is described as "everything else that has uniqueness, beauty, and importance in the form of a diversity of natural, cultural, and man-made resources that are targeted or visited by tourists," according to Law No. 10 of 2009. Those rivers, Tukad Bindu and Tukad Badung, have been revitalized and developed into tourist attractions. The municipality of Denpasar is trying to revitalize the river in an effort to adapt to areas that are vulnerable to flooding during the rainy season, which is supposed to increase the city's environmental sanitation. In addition, Denpasar Mayor Rai Mantra announced in 2016 that he would clean up the river's upstream and downstream sectors, as well as create it a destination for education, recreation, sports, and improving the community's economic business. The Denpasar City Government is trying to change the watershed area, which used to be a slum, into something like a tourist attraction with the objective of generating clean rivers and alternative tourism. In addition to the development of tourism in Bali, including environment tourism, citizens in the Tukad Bindu sector created the Tukad Bindu Foundation as a representative of the surrounding community. The clean river program, which would be the flagship program of the Denpasar
City government, has been created to manage and revive nature conservation. The Ayung River Watershed area, specifically Tukad Bindu in Kesiman Village, is one of the government's issues.

The Denpasar City Government and the Tukad Bindu Foundation also have cooperation connections that help to achieve the clean river program. The impact felt by the revitalization of this river border can be used as a forum for creation and creativity that is useful for the community, both in the fields of education, social and humanity so that nature or river conservation can be enjoyed by the surrounding community. This is as expressed in media online tribun on 2018 related to the former being a waste disposal site. Currently, Tukad Bindu is a beautiful tourist location. In this news, it is explained that currently, Tukad Bindu is used as a playground, vacation spot, recreation area, and for study. Previously, Tukad Bindu was a haunted (spooky) place as well as a garbage dump for the community. Now it has become a famous tourist attraction and also a successful community-based area until it was visited by the IMF-World Bank delegation on October 9, 2018. What happened

The same thing occurred in Tukad Badung, where the river flows through the Denpasar City area and has a 
central and strategic role such as providing drinking water and irrigation water. According to [1], the condition of the water at the mouth of the Badung River in Denpasar City has been polluted by organic materials such as domestic waste. Efforts have been made by the Denpasar City government to manage environmental conditions along the border and the Badung river, namely the clean river program (prokasih) carried out by other cities in Indonesia such as Jakarta and Surabaya. The arrangement of the border tukad Badungis in the middle part along the Badung river, which is located on the edge of Jalan Sulawesi No.1 Denpasar, which borders and is adjacent to the Badung Market and Kumbasari Market, which are traditional markets.

The development of tourism has made Tukad Badung a tourist attraction in Denpasar City. The positive impact is also felt by the Denpasar community because with the revitalization of the river border which is used as a place for recreation, the surrounding community has a place to relax and add tourist attractions in the midst of the crowded city of Denpasar. One of the phenomena that occurred was revealed in mass media online that Tukad Badung was used as a place of recreation (Nusa Bali, 2017). This news explains that Tukad Badung, which is located between Badung Market and Kumbasari, whose river repair process is being carried out starting June 22, 2018 is targeted for completion on December 17, 2018, which is designed to later become a place of recreation for residents in Denpasar City. The development of a riverbased tourist attraction in Denpasar City is certainly expected to have an impact on the economy, society, and the environment. Of course, the potential of the Tukad Bindu and Tukad Badung borders as a tourist attraction will have an impact on the economy, social and culture. This is because the river that used to be a garbage dump and a haunted place has now been neatly arranged into a new river-based tourist attraction in Denpasar City.

\section{METHOD}

This research is qualitative research examining the impact of the utilization of river tourist attractions in Tukad Bindu and Tukad Badung, which are located in the Denpasar area. Data collection techniques used are observation, interviews, literature study and document techniques. Informants were determined using two snowball and purposive sampling techniques. The data analysis used is: descriptive qualitative analysis in this study is used to analyze the impact on the tourist attraction of the Tukad Bindu and Tukad Badung rivers in Denpasar. In this study, interviews were conducted starting in 2019 in February until 2020 in January, which was approximately one year. The data gathered is also very useful in writing this research.
This study observed two tourist attractions, namely Tukad Bindu and Tukad Badung. The interviews conducted were direct interviews with parties related to the tourist attraction of Tukad Bindu and Tukad Badung by conducting interviews with local residents, then with the Head of the Tourism Attractiveness Section of the Denpasar City Tourism Office, Denpasar Public Works Department staff, Head of Pemtrantib and Pemecutan Village Cleanliness. Denpasar, head of the management of the Tukad Bindu foundation and its members, traders who sell in Tukad Bindu and Tukad Badung, as well as visitors in Tukad Bindu and Tukad Badung

\section{RESULTS \& DISCUSSION}

An analysis of the impact of using the river border as a tourist attraction is discussed one by one, namely Tukad Bindu and Tukad Badung. Impact analysis in this study focused on three things, namely the economic impact. Socio-cultural impacts as well as environmental impacts. The following is a study of Tukad Bindu and Tukad Badung.

\subsection{Tukad Bindu}

Tukad Bindu as a tourist attraction is carried out by the Tukad Bindu Foundation in synergy with the government, especially Denpasar City, which has occurred since 2017 to make the area productive. In an effort to make Tukad Bindu a productive area, the government has improved border infrastructure along the banks of the river and provided facilities to support tourist attractions. Tukad Bindu is a tourist attraction that has the potential to be a place of recreation for children, teenagers, parents, and families (Fig. 1). Tukad Bindu also provides buoys, tires and canoes as a means of playing in Tukad Bindu. Tukad Bindu also provides several fitness facilities, several children's play facilities and a neatly arranged garden and there are also stalls selling various food and drinks along the Tukad Bindu border.Besides that, the existence of facilities such as free internet access for visitors and the presence of halls to relax make Tukad Bindu's tourist attraction crowded with people. Changes that occur in Tukad Bindu as a tourist attraction will certainly have an impact on the economy, society, and the environment around Tukad Bindu.

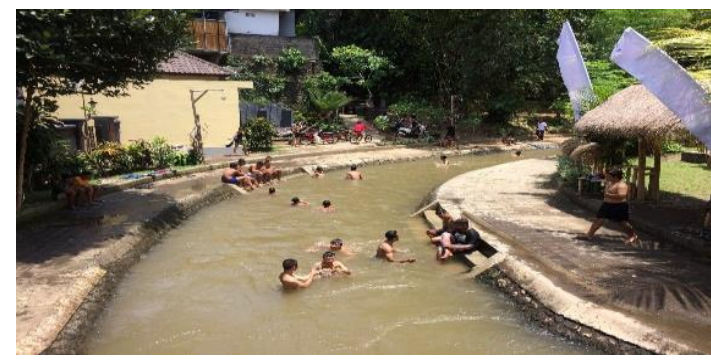

Figure 1 Tukad Bindu as a Tourist attraction 


\subsubsection{Economic Impact}

According to [2], there are impacts from tourism, namely the impact on the economy, socio-culture, and the environment. According to Cohen [3], the economic impact caused by the creation of a job opportunity is palpable. In this case, it is explained that there are several countries that have developed the tourism sector. It is proven that the international tourism sector contributes significantly to the creation of job opportunities and the creation of tourism-related businesses. The utilization of the development of Tukad Bindu as a tourist attraction also has an impact on the creation of jobs. The current condition of the use of Tukad Bindu as a tourist attraction can be said to have an impact on the economy of the surrounding population. One of the managers of the Tukad Bindu foundation, Ida Bagus Made Ary Manik, SS, stated that the revitalization of Tukad Bindu became a tourist attraction and had an economic impact.

This is evidenced by the existence of various food stands around the Tukad Bindu border (Fig. 2). The traders who sell in Tukad Bindu are also mostly people who live in that area. One of the traders in Tukad Bindu, Ketut Bawa, stated that by selling in Tukad Bindu, he was able to increase the economy by earning an income of two hundred thousand when it was crowded with visitors. The existence of one of the economic impacts caused can be said that the utilization of Tukad Bindu as a tourist attraction has had an impact on improving the welfare of several local residents. Not only can international tourism development contribute to the creation of job opportunities, but the utilization of the development of the Tukad Bindu river-based tourist attraction can also create jobs, even for some local residents (Fig. 3 and Fig. 4).

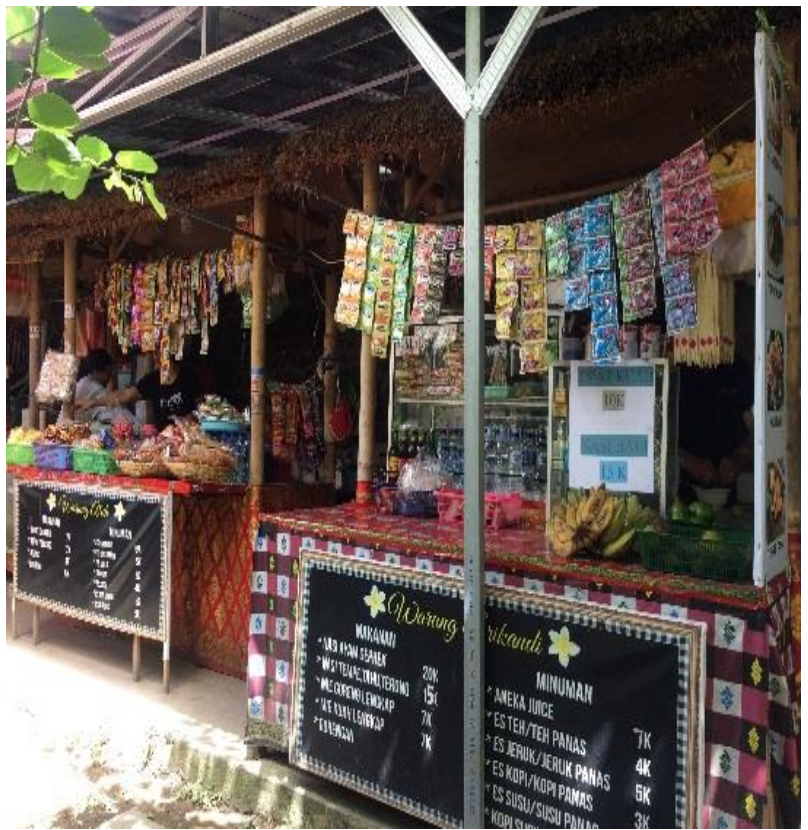

Figure 2 Some of culinary in Tukad Bindu

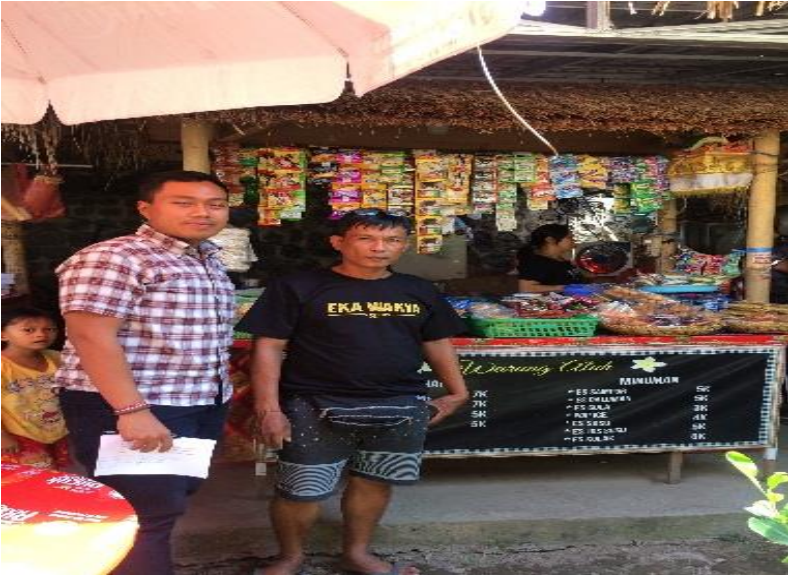

Figure 3 One of the food merchants

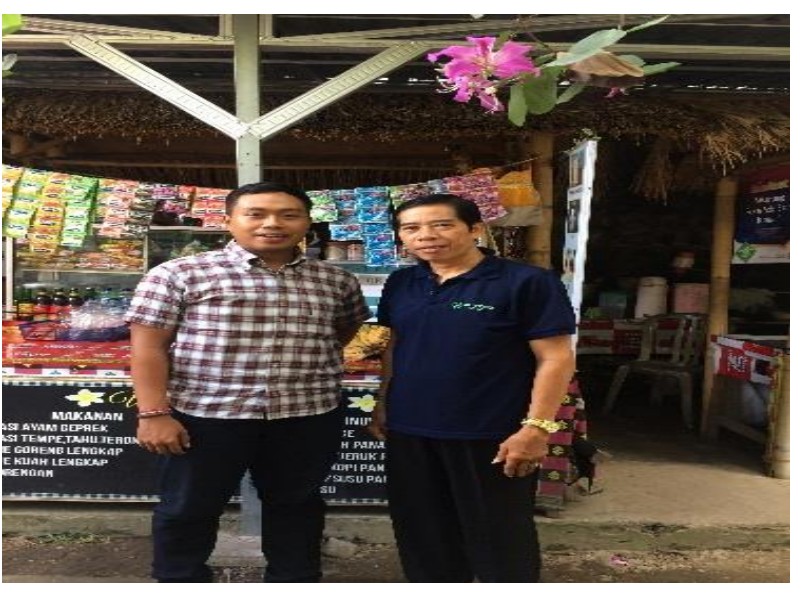

Figure 4 One of the food merchants

\subsubsection{The social and cultural impact}

Tukad Bindu as a tourist attraction has a social and cultural impact. The existence of social and cultural impacts can be said as changes in social and cultural norms in social life. According to [3], the model of irridex from Doxey explains the changes in local communities towards tourists in a linear manner. Euphoria means tourist arrivals are well received, with a million expectations. Tourists who visit the Tukad Bindu border are well received by the community. The community does not feel disturbed by tourist visits. Apathy means society accepts tourists as something normal, and the relationship between the community and tourists is dominated by commercial relations. The current condition of the community is that it is commonplace to receive tourist visits. This is also considered by the number of tourist visits that affect the income of traders who sell. In addition, the cultural performances carried out also have an impact on the number of visitors and the sale and entertainment of tourists' culture. 
Other social and cultural impacts that occur as a result of changing societal trends include: Trends can be described as a new culture that occurred in its time. Changes in the trend of people doing recreation on the river have occurred in the current generation (Fig. 6). If the Tukad Bindu border river is not repaired, it is likely that there will be no place for community recreation to go to the river again. Besides that, the changes that have occurred in the cultural aspect have an impact on the cultural aspect, namely in the tradition. Where previously, religious traditions such as dances were used as symbols in religious ceremonies, they have now shifted to become part of a tourist attraction by displaying a dance as a selling point for a tourist attraction, which attracts visitors (Fig. 5).

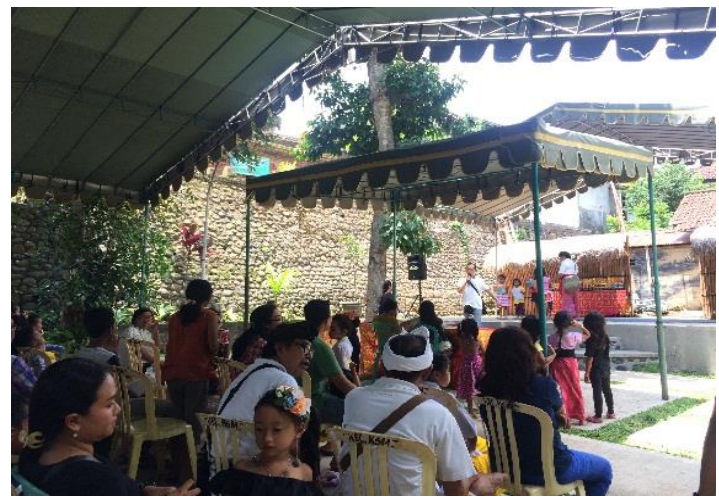

Figure 5 Event in Tukad Bindu

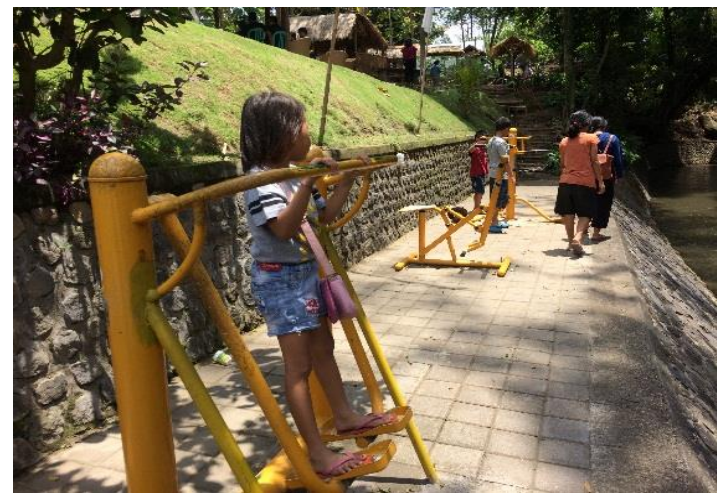

Figure 6 Tukad Bindu as a place for sport recreation

\subsubsection{Environment impacts}

Besides that, the development that has taken place in the improvement of Tukad Bindu into, a tourist attraction, certainly has an impact on the surrounding environment. such as the impact of the use of means of transportation, the means of transportation used to support tourism activities, especially in connecting between the areas of origin of tourists and tourist destinations. Tukad Bindu used to be a tourist attraction before it became a tourist attraction. Very few people passed through Tukad Bindu, only people around who passed through Tukad Bindu on foot. But the changes that are happening now are very big. Since Tukad Bindu has become one of the tourist attractions in Denpasar City, many tourists come to visit this place. Of course, to get to this place, you can use motorbikes, cars, and large buses. The existence of such a thing will certainly create noise pollution, namely noise due to the sound of the vehicle and vehicle exhaust gas pollution. This, of course, will also have an impact on the air and tranquility in Tukad Bindu. Besides, the location is close to the main road.

\subsection{Tukad Badung}

\subsubsection{Economic Impact}

The utilization of the development of Tukad Badung as a tourist attraction also has an impact on the creation of jobs. The condition of the utilization of Tukad Badung as a tourist attraction can be said to have an impact on the economy. Jobs created from this utilization are the existence of traders (Fig. 7) who sell near the border and the addition of cleaning workers from the government. As said by one of the traders in Tukad Badung, Luh Rai, who stated that by selling around Tukad Badung, you can earn two hundred to three hundred thousand if there are many visitors who arrive. In addition, because the location of the river that coincides with this market makes the surrounding community participate in selling in the market because it is supported by an interesting thing, namely the Tukad Badung tourist attraction which makes more and more visitors who affect selling in the market. With the economic impact caused, it can be said that the use of Tukad Badung as a tourist attraction has had an impact on improving the welfare of several local residents. Not only international tourism development can contribute to the creation of job opportunities, but the utilization of Tukad Badung development into a river-based tourist attraction can also create jobs such as traders, parking attendants and cleaners (Fig. 8).

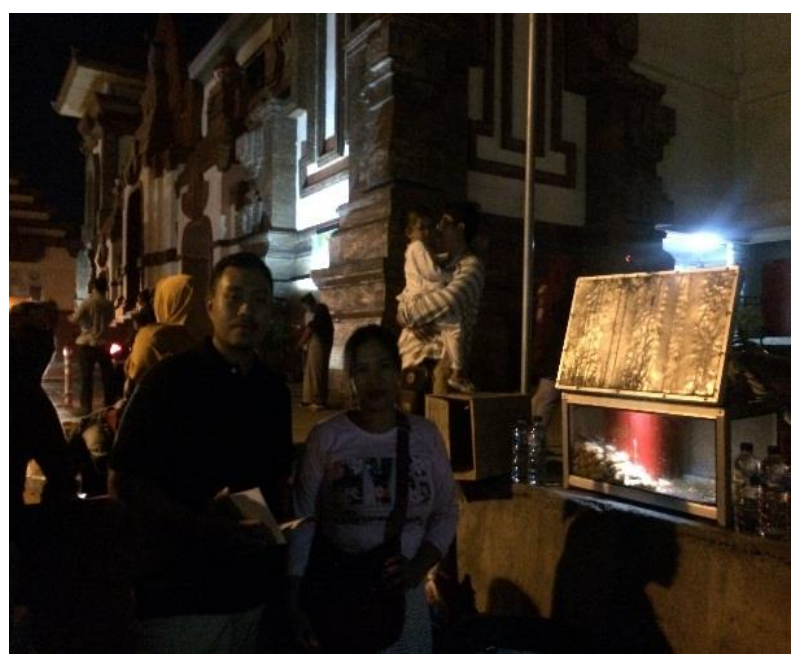

Figure 7 One of food merchant in Tukad Badung 


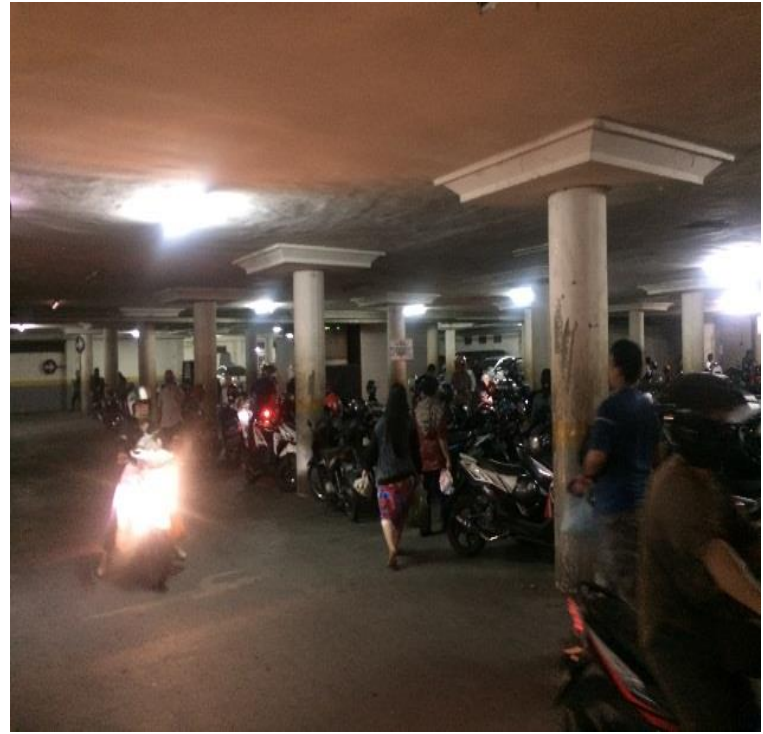

Figure 8 Parking Area in Tukad Badung

\subsubsection{The social and cultural impact}

Tukad Badung as a tourist attraction causes social and cultural impacts. The existence of social and cultural impacts can be said as changes in social and cultural norms in social life. Tourists who visit the Tukad Badung border are well received by the community. The community does not feel disturbed by tourist visits. The absence of people who are disturbed by the presence of tourist visits proves that the arrival of tourists is very well felt and accepted by the community. The community is very enthusiastic and supports the existence of a river-based tourist attraction in Denpasar City (Fig 9, Fig. 10, and Fig. 11). The current condition of the community is that it is commonplace to receive tourist visits. This is also considered by the number of tourist visits that affect the income of traders who sell. In addition, the existence of cultural performances or music concerts (Fig. 11) that are carried out also has an impact on the number of visitors and the sales and entertainment of cultural tourists.

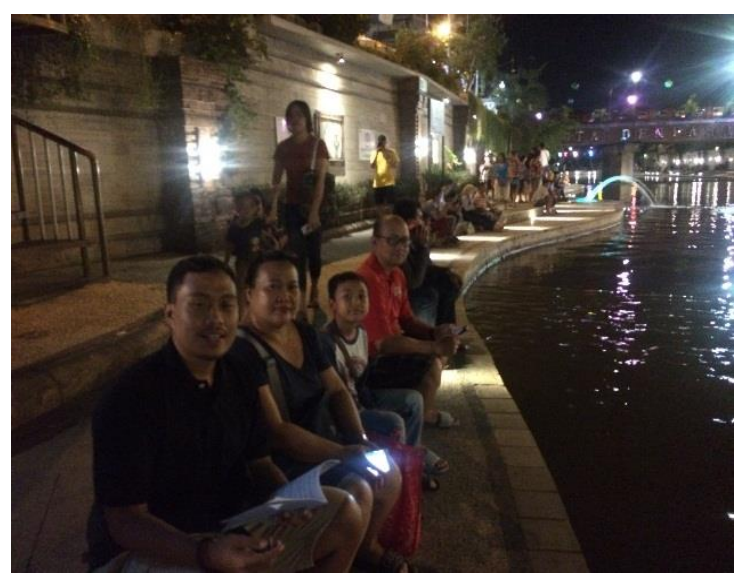

Figure 9 Some of family doing recreation in Tukad Badung

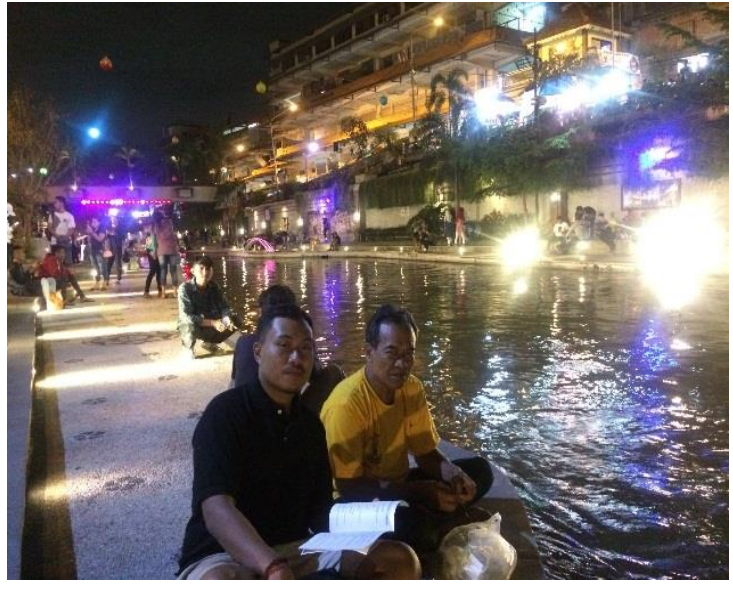

Figure 10 People doing fishing at the moment

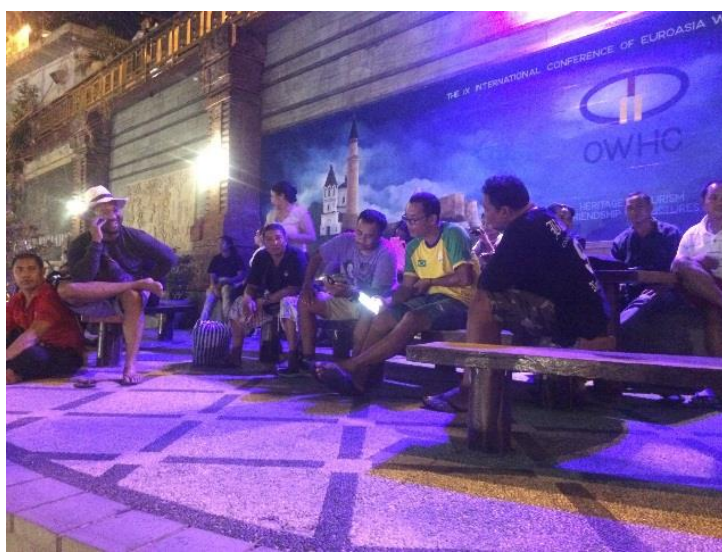

Figure 11 People doing group discussion in Tukad Badung

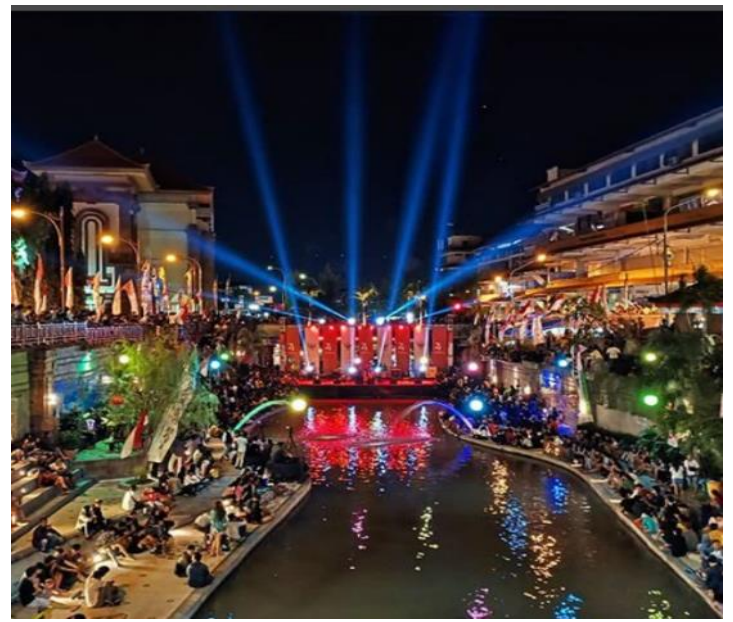

Figure 12 Event in Tukad Badung

\subsubsection{Environment impacts}

Tukad Badung as a tourist attraction has had an impact on the development of the environment and its infrastructure. The impact that is generated can provide benefits by arranging the Tukad Badung border. In the 
past, where the condition of the Tukad Badung border could be said to be not good, after the revitalization and structuring of the border it was used to facilitate access to walk on the riverbank, and make it easier if later there was an improvement in the access of the border to be rearranged. Of course, the improvement of the border in Tukad Badung as a tourist attraction brings the river environment to be more beautiful and attracts people to visit. Besides the things that have a good impact on the environment, the utilization of the border at Tukad Badung as a tourist attraction certainly brings a side that has a negative impact on the environment of the Tukad Badung border, which is now a tourist attraction. As it is known, Tukad Badung is located close to the main road in Denpasar City, namely Jalan Gajah Mada. The current condition of Tukad Badung as a tourist attraction makes many people come. Of course, this will have an impact on the surrounding environment. In the past, Tukad Badung was almost rarely visited by the river area. People tended to go to the traditional market without looking around the Badung river, which is near the market. However, this makes the atmosphere around Tukad Badung calmer and less noisy and pollution is greatly reduced before it becomes a tourist attraction.

\section{CONCLUSION}

Based on the results of the research, it can be concluded that the impact of the utilization of Tukad Bindu and Tukad Badung tourist attractions affects the economic, socio-cultural and environmental sectors. Each tourist attraction has the same economic impact, namely the opening of new jobs and helping the surrounding economy by selling around the tourist attraction. In addition, another impact is that the surrounding community has begun to open up and get used to the arrival of visiting tourists. Meanwhile, because of the environmental impact itself, there are changes in infrastructure that make the river a tourist attraction. However, there are still shortcomings, namely when the rainy season comes, the river water becomes higher, which sometimes causes flooding, and the river water becomes dirty. Besides that, another thing that disturbs me is the increase in noise pollution and air pollution caused by vehicles brought by visitors. It is suggested to the management, government and the community to provide mutual support to maintain the existence of Tukad

Bindu and Tukad Badung tourist attractions by conducting promotions or introducing these tourist attractions. To keep the river environment clean and beautiful, other things are also shown to the public for awareness, such as not to throw garbage or household waste into the river.

\section{REFERENCES}

[1] I. Putu Eryani, I. Sinarta, and I. Surayasa, "Perubahan Fungsi Lahan Di Muara Sungai Terhadap Pelestarian Sumber Daya Air," Bumi Lestari, vol. 14, no. 1, pp. 85-90, 2014, doi: 10.24843/blje.

[2] Suwena and Widyatmaja, Pengetahuan Dasar Ilmu Pariwisata. Bali: Penerbit Pustaka Larasan.

[3] I. G. Pitana and K. S. Diarta, Pengantar Ilmu Pariwisata. Yogyakarta: Penerbit Andi, 2009. 